\title{
CD30-Positive Neoplastic Cells Present
}

National Cancer Institute

\section{Source}

National Cancer Institute. CD30-Positive Neoplastic Cells Present. NCI Thesaurus. Code C39715.

A finding that a sample of neoplastic cells has detectable immunoreactivity for CD30 (TNFRSF8). 